\title{
GENDER ASPECTS OF INHERITANCE MANAGEMENT IN GEORGIA CULTURAL PRACTICES VS LAW REGULATIONS
}

Maia Araviashvili

Ilia State University, Georgia

E-mail: m_araviashvili@yahoo.com

\begin{abstract}
After gaining independence in 1991 Georgia adopted the new constitution, received liberal laws and joined international conventions, which formally guarantee gender equality. However, law regulations do not come in accordance with cultural values, and are not shared by society. Consequently, the problems of gender inequality are still vital issues in Georgian society.

Traditionally, informal practice of dowry giving protected women and gave them independence in a new family. Nowadays, in Georgia a daughter and a son formally have equal access to their parent's inheritance, but there are very rare cases when a woman demands her part of it. This is not justified by society to contend for the inheritance with a brother. Formal institutions are not strong to prevent this economic form of domestic violence.

The methodology of the research is complex: expert interviews were recorded and analyzed, to study data about the inheritance registration and court records pertaining to inheritance litigations, the method of content analysis was used; apart from this, ethnographic resources and surveys were examined. The findings of the proposed research article provide a complex picture of this really vital problem still affecting the post-soviet Georgian society.
\end{abstract}

Key words: culture, gender, inheritance, law, and management.

\section{Introduction}

Gender equality remains a vital issue in both scientific research and everyday life, especially in so-called 'developing countries'. However, some forms of family and domestic violence often do not appear in discussions and research about gender equality. In Georgia, for example, only physical, psychological, and/or sexual forms of violence against women can be treated as gender discrimination, while some other forms of domestic violence are difficult to even discuss publicly. The economic form of violence, in particular, is one of the important but less studied themes of injustice and discrimination against women. Within Georgian society, economic violence is mainly discussed in the context of employment and not in the context of inheritance distribution, though the latter is the significant component of economic and structural forms of violence. Even though liberal legislation in Georgia gives women equal access on parents' property, cultural norms and traditions are so strong that in most cases women stay without inheritance. Some women consciously reject to use their rights on parents inheritance and others just are not informed about their rights at all. 
PROBLEMS

OF MANAGEMENT

IN THE $21^{\text {st }}$ CENTURY Vol. 9, No. 3, 2014

184
Women's inheritance rights in Georgia underwent striking changes throughout the centuries. In the medieval period, for example, a woman's belongings were separated from the property of her husband's family and remained under her control (Machabeli, 1978, p. 58). Generally, a woman's property consisted of a dowry allocated by her parents, and presents or money that future husband gave to the bride's family. The amount of a woman's dowry or property holdings was regulated mainly by traditions and customs. Dowry traditions varied in different regions of Georgia, but a dowry giving was a widespread practice to transfer parents' property to their daughters. As mentioned above, this inherited property exclusively belonged to the woman in her new family; she had the right to manage it and use it according to her will; and, in the case of divorce, the woman still owned that property (Machabeli, 1978, p. 56).

The nineteenth century was a hard time for many members of the Georgian nobility as they lost power and wealth following the weakening of feudalism. Therefore, due mostly to economic reasons, it became more difficult to follow the dowry-giving traditions. However, this custom still played an important role in Georgian culture, and the dowry remained an important prerequisite for women to get married and have significant economic rights in their new families. Generally, women had no right to choose their partner. Only parents had authority to plan their daughter's marriage and make financial arrangements with their future son-in-law. At that time, it became even more important for men from aristocratic, but economically downtrodden families to marry rich women whose dowry would improve their families' financial situation (Machabeli, 1978, p. 57).

In the wake of Capitalism economic and social differentiation based on property became more evident also within peasantry of the nineteenth century. Some peasants became promoted merchants and the part of the new bourgeoisie class. On the one hand, that class tried to establish a connection with noble families and gain more high-status position, on the other hand, nobility tried to prevent poverty and get property by marring "well dowered" women (Machabeli, 1978, pp. 32-35). New socio-economical conditions stipulated new rules of marriage norms at that time. Even though, dowry giving somehow lost its meaning, it had been remained as a tradition. Pierre Bourdieu notes that the norms people follow are 'ongoingly' reproduced. Perhaps dowries kept their importance and meaning in the modern era, because families were united by paths that continuously were kept from generation to generation, "about which nothing is said, as with everything which can be taken for granted because it has always been as it is" (Berger \& Luckmann, 1967, p. 24).

In Soviet times, the practice of giving dowries was not as strong as before, but it remained an important tradition. It was not obligatory for parents to give a dowry to a daughter, but in some social groups leaving a bride without dowry could become a subject of criticism. Generally, a bride's family was expected to bring furniture with bedclothes to the house of the future husband. A man, in his turn, mostly was supposed to have a house. Thus, while dowries may have become a sort of unspoken tradition, they were far from meaningless.

In 1921 the family law was amended in order to "destroy the elements of women's exploitation," or, in other words, to reject economic, religious, class, and national barriers in regards to marriage, and to eliminate parental involvement in the creation of new families. Only mutual personal consent was declared as a precondition for marriage. The Soviet Georgia's ethnographic data clearly reflect this shift (Beqaia, 1981, pp. 60-61). The former customs became old fashioned and women's property now mostly consisted of her work salary, rather than her inheritance or dowry.

After the collapse of the Soviet Union, Georgia joined various international conventions and approved laws for the protection of human rights. However, it seems that all these steps were made to meet international standards, since the country still does not have mechanisms to make law regulations function in reality. It is not surprising that in what is still a patriarchal society, cultural norms override the law, especially in regard to women's rights. 
The Constitution of Georgia (August 24 ${ }^{\text {th }}$, 1995) guarantees equality for all citizens in Article 14: "Everyone is born free and is equal before the law, regardless of race, skin color, language, sex, religion, political and other beliefs, national, ethnic and social origin, property and title status or place of residence." Besides that, Georgia's inheritance law gives equal access to property inheritance and does not differentiate based on gender. The Law of Inheritance, Article 1307, defines persons in the event of hereditary succession, who may inherit a property, as descendants of the deceased, as of the moment of his death, as well as any descendants born after the parent's death.

The country also approved the Law on Gender Equality in 2010. Some articles of this law address the main subject of this paper. The Gender Equality Law additionally supports gender equality in terms of equal opportunities and treatment. Also, it frames parents' rights and responsibilities towards their children. This law also stresses the importance of maintaining statistics on gender inequality (Gender Equality Law of Georgia, 2010).

In order to establish a strong democratic rule of law, citizens' actions should reflect deep ethical and moral convictions on what is just or unjust, as citizens must be willing to share the responsibility to create and sustain institutions and laws. "Perhaps the most important responsibilities of citizens are to make appropriate use of their liberty and to respect the rights of others" (Galston, 1997, p. 7).

But in most cases, some types of gender discrimination are not admitted as violence at all and are considered justified, making it especially difficult to combat. In most cases, ordinary citizens do not accept new laws regarding gender equality. Moreover, "even though the law guarantees gender equality, traditional views and women's acknowledgment of their rights give privileges to men" (Sabedashvili, 2007, p. 37).

To examine how these laws are represented and reflected in everyday life, we should consider data from previous studies. For example, Nani Bendeliani's article 'Assessing Gender Equality in Georgia on the Basis of International Indices and Ratings' (Bendeliani, 2012) is a comprehensive evaluation of gender equality problems in Georgia from various perspectives and methodologies. This work is based on records of different international agencies and also deals with the issues of gender discrimination in terms of inheritance distribution. The author discusses two reports that evaluated gender equality in Georgia in 2009 and 2012 (Bendeliani, 2012). The data reveal, that gender inequality problems with regard to inheritance rights actually worsened between 2009 and 2012. For instance, on the scale used in the study, 0 means that social institutions do not influence the majority of women, and 1 means that social institutions do have influence on the majority of women. According to this scale, Georgia was evaluated with 0 in 2009 and 0.5 in 2012 in respect of unequal access to the inheritance. The author explains this paradox: "[The] 2009 report falls short to reflect the effect of institutions over gender equality in Georgia - it measures formal, legislative indicators, not so relevant to the reality existing in Georgia. In the 2012 report, the indicators measuring the informal institutions were included in the index" (Bendeliani, 2012, pp. 18-19). It is remarkable that on the formal and legal levels we are evaluated with excellent results, but problems arise as soon as the reality and significance of informal institutions are discussed.

Another source that could be useful to analyze is the data from research conducted in 2013 by the UNDP (United Nations in Georgia, 2013, p. 201). The research results were gained by using both quantitative (survey) and qualitative (focus groups) methods. One of the research topics was the women's rights on property and inheritance. According to the survey, a high number of respondents believed that a major part of a parent's property, or even all of it, should be given to a son, making it quite evident that men have a privileged position within society in terms of inheritance rights (United Nations in Georgia, 2013, p. 201). 
PROBLEMS

OF MANAGEMENT

IN THE $21^{\text {st }}$ CENTURY Vol. 9, No. 3, 2014

186

\section{Problem of Research}

In Georgia new values are not formed and traditions still play an important role in shaping social practices. The law does not come in accordance with cultural values, which traditionally rule "accepted" acts. In this way, equality of rights mentioned in Georgian Constitution and law, is not shared by society. The unequal distribution and management of inheritance is not seen as unfair. In most cases, neither men nor women evaluate it as unjust. Georgian women cannot protect their rights conceded by the law, that's when the privileged division of inheritance has led to the development of unequal positions for men and women in regard to power and social status not only in the family but also in the society.

\section{Research Focus}

This research focuses on gender inequality in the context of inheritance management, which in my opinion appears to be one of the main forms of economic violence in Georgian society. Although the Georgian Constitution guarantees gender equality, and Georgia's property law gives sons and daughters the same legal rights to inheritance, the legal system often comes in conflict with cultural practices that favor men in terms of inheritance rights. The study will analyze the factors of Georgia accepted liberal law regulation that should protect women's rights and will also describe the difficulties of implementation process. The research will analyze how inheritance managements affect gender roles in Georgian families, and how inheritance management can become a form of economic violence and source of other forms of violence.

\section{Research Methodology}

To study the issue combined methodology was needed, that could give the full picture. Within this research following methods were used: the expert interviews, the content analyses of data retrieved from the National Agency of Public Registry and Public court, also content analyses of the dowry books.

As qualitative research gives opportunity to get in depth information to find the reasons and factors of the problem, expert interviews were recorded with scholars in gender studies and lawyers specializing in inheritance laws and human rights. A group of experts that were interviewed are: Mzia Tsereteli, professor of psychology at Ivane Javakhishvili Tbilisi State University who works on gender issues. She is an author of a book Gender-A Cultural and Social Construct; Lela Khomeriki, professor of psychology at Ilia State University, studies and teaches gender related problems. She issued a book entitled as Gender and Politics; Nino Javakhishvili, professor of social psychology at Ilia State University, investigates various aspects of gender issues reflected in her publications; Tamar Gurchiani, a lawyer and public activist specializes in gender equality, human rights, transparency, free and democratic elections; Lela Taliuri, a lawyer at Georgian Young Lawyers Association; Nino Chikladze, a lawyer at Georgian Young Lawyers Association works on various gender projects; Teimuraz Koridze a lawyer and advocate in civic law; Vakhtang Mosiashvili a lawyer and advocate in civic law. The expert interviews were recorded during March-April, 2014. The research instrument was the discussion guide. After gaining records the transcripts were prepared and the data was analyzed.

Apart from this, the method of content analysis was used to study data about the inheritance registration at the National Agency of Public Registry and inheritance litigation cases at the court. The three major cities were chosen, one from eastern and another from western part, and also the capital of Georgia to request the public information (mainly the statistics). On the one hand, the identical letters were sent to the National Agency of Public Registry in 
three Georgian cities: Tbilisi, Telavi, and Kutaisi. The requested public information should contain the registered inheritance data for 2011-2012, 2012-2013 and 2013-2014 years and gender aspect, the quantity of the registered inheritance for men and women. On the other hand, the matching letters were sent to the Tbilisi City Court, Kutaisi City Court and Telavi District Court, that were also asked for court records, pertaining to inheritance litigations for the last three years. The information should have covered quantity of inheritance litigation and gender aspects: between whom the process was. Field work of this method proceeded February-March, 2014.

\section{Law Regulations and Cultural Practices}

As mentioned above, the Constitution of Georgia guarantees equality for all citizens and the Law on Gender Equality supports equal opportunities and treatment, at the same time it stresses the significance of maintaining statistics on gender equality. In this part, the accordance between law regulations and everyday practices will be discussed.

To turn to the content analyses of the data that was retrieved from the Tbilisi and Kutaisi city courts, the Telavi District court, and the National Agency of Public Registry. It is important to note that even though the Gender Equality Law instructs public institutions to gather, sort, and maintain statistics in the sphere of gender equality, two important institutions, such as the court and the National Agency of Public Registry, do not do so. When the National Agency of the Public Registry was asked for information regarding the gender of registered inheritance beneficiaries from 2011 to 2013, only general statistical information was given and the agency responded that they do not possess information on the gender of beneficiaries. Although it is legally considered public information, when the names of beneficiaries were requested in order to create statistics according to gender, the agency responded that the information would only be supplied for a fee of ten GEL per name. Consequently, this data, which is supposedly free to the public, would be incredibly expensive to acquire, given that in only one year these three cities have approximately six thousand and five hundred inheritance claimers. Furthermore, an application for this data was rejected due to the amount of time and difficulty required to compile the information. When Tbilisi City Court was asked for information, it released on the number of inheritance litigations that took place. The Only Telavi District Court was able to provide the requested statistical information about inheritance litigations between sisters and brothers for the years covered in this report.

These cases reveal that sometimes key public organizations are not involved in implementing gender equality law, and do not systematize related data as they should. It is very important to maintain gender varied statistical data in order to plan future policies related to gender. As Lela Khomeriki notes, statistics can play a significant role in raising awareness about gender inequality in society (L. Khomeriki, interview by author, Expert Interview, Tbilisi, Georgia, March 2014). To support this claim, she recalled examples from her teaching experience at Ilia State University in Tbilisi, particularly from her class about gender issues in Georgia. Often, students did not admit that gender inequality exists in Georgia, until they were shown supporting statistical data. When they encountered real facts, they began to reflect on them and acknowledge injustice or discrimination toward women.

For Tamar Gurchiani, it is clear that there are no gender sensitive institutions in Georgia that could survey and compile statistics on gender issues; for example how many women refuse to receive their parents' inheritance and why. Another problem she mentions is, that Georgia does not have proactive law regulations that could decrease the number of women who do not claim or have to refuse their share of inheritance (T. Gurchiani, expert interview by author, Tbilisi, Georgia, March 2014). 
PROBLEMS

OF MANAGEMENT

IN THE $21^{\text {st }}$ CENTURY Vol. 9, No. 3, 2014

188

The survey, conducted by UNDP shows, that most of the parents' property is given to a son and not to a daughter. (United Nations in Georgia, 2013, p. 201). But still the significant part of the respondents supported equal rights in terms of inheritance distribution, but it is unclear what this idea of "equal rights" pertains: Does it mean a fully equal and just experience, or only a subjective vision of what is considered "fair"? Furthermore, it is unclear whether these respondents would themselves distribute their property evenly to their children, or whether they had a fair experience when receiving their own inheritance. As the survey shows, the number of people who believe that a major part of parents' property should be given to a daughter is very small (United Nations in Georgia, 2013, p. 201).

Table 1. Division of inheritance (\%).

\begin{tabular}{|c|c|c|c|c|}
\hline \multicolumn{5}{|c|}{ Question - How should parents' property be divided between son and daughter? } \\
\hline \multirow[b]{2}{*}{ Answers } & \multicolumn{4}{|c|}{ Property type } \\
\hline & $\begin{array}{l}\text { Parents' } \\
\text { house }\end{array}$ & Land & Jewellery & $\begin{array}{l}\text { Cash, car and other } \\
\text { mobile property }\end{array}$ \\
\hline Should be given completely to a son & 42 & 31 & 7 & 14 \\
\hline Major part should be given to a son & 14 & 16 & 12 & 16 \\
\hline Should be divided equally & 44 & 50 & 67 & 66 \\
\hline Major part should be given to a daughter & 0 & 1 & 11 & 3 \\
\hline Should be given completely to a daughter & 0 & 1 & 3 & 1 \\
\hline Don't know/refuse to answer & 1 & 1 & 1 & 2 \\
\hline
\end{tabular}

The data from the table division of inheritance shows that respondents more easily give women access to movable property than to unmovable property. Georgians predominantly prefer men to inherit a house and land (United Nations in Georgia, 2013, p. 201).

Qualitative research data of the same project support the quantitative research results. Respondents explain giving preference to a son, and compensate a woman with a dowry as reflected in the Georgian tradition. When getting married, a woman is believed to become the 'owner' of her spouse's property, including his inheritance from his parents. However, here 'ownership' means just a right to use the property (to live in a house, to use belongings). Here are some comments from female respondents:

I think that the son should be given more; everything my father left belongs to his son. I would not take what my father left for him. I do not want my brother's property to be shared with me (Samegrelo, urban, 20-35, higher education) (United Nations in Georgia, 2013, p. 201).

We sold our house in Gali, I have a sister-in-law and we symbolically...My husband symbolically gave her $\$ 300$. She had no complaints. I would be very offended if she had and I as well do not want anything from my brother's house, even if they sell it, I do not want even one Tetri. (Samegrelo, urban, 36-50, higher education) (United Nations in Georgia, 2013, p. 201).

I have a house in a village and a flat in a city and it happened somehow that I have it in my daughter's name. It does not matter whose name it is in, but my son asked me several times why it is in Salome's name. Therefore, he thinks that he has a house in a village, and that both belong to him. Now, I have never said at home that it all belongs to a son, but I 
guess he still thinks that it still belongs to him (Samegrelo, urban, 36-50, higher education) (United Nations in Georgia, 2013, p. 201).

Dividing property, unfortunately, it is that in Georgia that when a daughter is married and leaves for her new home, that is where her property is. Whether it is bedroom furniture, a dowry, or others - whatever was sent to her, but now as I notice...everything was given to a son: house, land or whatever it was. (Kakheti, urban, 20-35, higher education) (United Nations in Georgia, 2013, p. 201).

It is clear, that even though democratic countries should share universal values about human rights, there is still a huge gap between the existing situation and the desired reality in Georgia. Women are victims of cultural norms, invisible repression, and violence. The laws and regulations promoting gender equality are either ignored or posited as unnatural in order to justify the legitimacy of Georgia's existing inequality. As Iris Marion Young declares, “... social justice requires explicitly acknowledging and attending to those group differences in order to undermine oppression" (Young, 2011, p. 3). She argues that when some groups are privileged in a society while others are oppressed, in order to achieve social justice, the oppression must be explicitly acknowledged and addressed. Tamar Gurchiani expressed the opinion of Georgian liberal circles when she mentioned that the Georgian Orthodox Church, as an institution, propagates conservative, patriarchal values, and supports gender discrimination and women's dependence on men. Given the fact that $96 \%$ of Georgians report that they trust the Patriarch (NDI, public poll in Georgia, March-April 2014), it would not be easy to change these deeply rooted discriminatory attitudes against women.

One of the biggest roadblocks for gender equality in Georgia lies in the lack of consensus about the definition and parameters of human rights, especially in regards to women's rights. In public discussions, issues involving gender equality are often mentioned with a touch of irony (Matynia, 2010, p. 201), even by liberal intellectuals who have significant influence on public opinion. Elzbieta Matynia discusses similar problems in Poland when "in those first years of transformation, there was enormous socio-cultural and political pressure coming from both men and women to disregard the issue and even to ridicule those involved in discussions of it" (Matynia, 2010, p. 206).

In most cases, even though gender inequality is apparent, it is not seen as injustice. Some forms of violence are seen as justified, as they are part of widespread social norms that condone such behavior. That's why gender inequality and violence against women needs adequate attention and research to reveal this oppression and injustice. A lawyer, Vakhtang Mosiashvili, notes that when parents distribute inheritance to their children and give priority to the sons they unconsciously put daughters in unequal positions. However, they do not treat this action as discriminatory against their daughters. If they were aware of the future consequences of their actions, they may not make these choices. "No parent hates his/her children. So, to destroy their future life and give no chance to live normally- it happens just unconsciously" (V. Mosiashvili, expert interview by author, Tbilisi, Georgia, March 2014).

Mzia Tsereteli notes that even women themselves do not admit that their rights are violated, since discrimination is perceived as a fact of life:

When you say, "Women you also can claim your share of inheritance!" they are surprised. Thus, they themselves are potential violators. If a woman understands that the inheritance belonged to her, too, and her parents treated her unjustly, it will be a progress, as she will not do the same to her children. Usually, daughters do not even express their anger, but emotionally they are full of displeasure. This tradition unconsciously passes from generation to generation, and women do the same to their children as parents treated them. They think this is the norm. Sometimes, women do not realize what they lost, for example, their chances of development and self-realization (M. Tsereteli, expert interview by author, Tbilisi, Georgia, March 2014) 
PROBLEMS

OF MANAGEMENT

IN THE $21^{\text {st }}$ CENTURY Vol. 9, No. 3, 2014

190

Peter L. Berger and Thomas Luckmann argue, "As long as the routines of everyday life continue without interruption they are apprehended as unproblematic" (Bourdieu, 2005, p. 66). They seem to be 'typificatory schemes' in everyday life and these schemes continuously affect interactions (Bourdieu, 2005, p. 66). In terms of sister-brother relationships we can see the 'typificatory scheme' of good brother and sister relationships based on the presumption that males are the only rightful inheritors. But these harmonious interactions only last until sisters ask for their share of their inheritance and acknowledge themselves as equal heirs of their parents' property. In that case, the "typificatory scheme" is ruined.

Mzia Tsereteli states that instead of inheritance, a woman gains the status of being married, which she finds more suitable. The 'modern' type of women irritates her, because that conflicts with the typification scheme of a 'good Georgian women':

As compensation a woman gets... a kind of status, a "pseudo" status... "the real Georgian woman," "a good housewife"... and she likes this kind of status and role (M. Tsereteli, expert interview by author, Tbilisi, Georgia, March 2014).

Even though, in many cases, common law is stronger than legislation, we cannot say that legislation is useless. According to Tamar Gurchiani, the inheritance law approved in 1997 protects women because in order to divide or sell the inheritance property, a claimant must stay within the framework of the law:

Even if an ancestor decided to distribute inheritance just among men and exclude women by the means of a testament and leave her without inheritance, the law supports her as a legal heiress. The law protects her, because the law does not make any difference based on gender (T. Gurchiani, expert interview by author, Tbilisi, Georgia, March 2014)

However, Gurchiani thinks that even though the law does not vary based on gender, structural discrimination is so strong that it disables women from accessing their legal rights:

If we say that cultural norms are so strong that they dictate women to reject their rights on inheritance for the benefit of men, then we can suppose that these kinds of cases are frequent... When a woman is an heiress, but she is a victim of discrimination, this injustice should not be discussed in just law regulation context. We face broader, structural discrimination that is sharply framed, supported by cultural norms. Structural discrimination is as important a problem as legal discrimination (T. Gurchiani, expert interview by author, Tbilisi, Georgia, March 2014)

Another lawyer, Teimuraz Koridze, claims that sister-brother litigation cases on inheritance occur very rarely as they do not want to address the court and bring the issue into public view. In many cases even though sisters are not satisfied with their conditions, they do not go to the court to claim their inheritance rights:

Legal litigations between sister and brother are rare and in most cases these happen as consultations. Sisters are interested in: do they have an inheritance? Do they have right on a parent's property? These cases do not come to the court as usual. But they have a feeling of protest towards the unequal inheritance distribution practice, while the law has different regulations. The reason they do not go to court is because they do not want people to discuss it. If women address the court then everybody, all relatives will know about it and this will be considered an embarrassing case (T. Koridze, expert interview by author, Tbilisi, Georgia, March 2014).

It can be seen that women, even in very hard situations, refuse to litigate with their brothers and parents. Nino Javakhishvili explains that issue: 
...because it's not only about her brother, she might ruin relations with a mother, father, grandmother, grandfather, and even with cousins. That means, for us, the family is the most valuable, we are a 'clan' society.

Vakhtang Mosiashvili also discusses the reasons why women do not sue their families:

This is a complex problem; in our society to intervene and take part in other lives seems normal. Women do not go to the court not because they do not want to, but because the society will respond in a very negative way. Deeply rooted stereotypes will come up and everyone will express their displeasure about 'shameless' women who dare to ask their brothers for a share of the patrimonial house. The same could happen if a brother addresses the court, as for Georgians it is not acceptable that brother and sisters sue over the property, they think that close relatives should have a more respectful relationship (V. Mosiashvili, expert interview by author, Tbilisi, Georgia, March 2014).

Sometimes women do not seek legal redress for financial reasons as they are unable to pay for legal services. Teimuraz Koridze notes:

Women should have enough financial support to begin legal litigation. They have to pay the lawyer in advance and if they lose the trial/process they will not get any refund. Apart from this, they should pay a fee for the court hearing and also for the property value expertise (T. Koridze, expert interview by author, Tbilisi, Georgia, March 2014).

Recently in Georgia, many women have become the breadwinner in their family, but that has not changed their social condition; they still are not equal with their partners in decisionmaking processes. Often, Georgian women are more concerned with supporting their family than defending their own rights. "Despite the fact, that in many households women have become the primary breadwinners, their better adaptability and survival skills have not facilitated their transition from the private to the public domain" (Sabedashvili, 2007, p. 36). They cannot fight against the patriarchal society that commands them to accept this set of norms. One of the reasons supporting these norms is the strong belief that men function as the continuers of the patrimonial line. Another factor is that the son often stays living with his parents, while the daughter moves to live with her husband's family. Sons are expected to take care of their parents, and this is often used to justify their claims to full inheritance of their parents' property. If parents have only male children, according to tradition, the youngest son is the primary heir as he stays in the parental house and cares for his parents, while elder sons have to move when they get married. A lack of economic resources is an additional obstacle for women to gain access to their inheritance. In particular, when parents have only one house they cannot divide it. Even if finances are of less consequence, parents prefer to give a daughter immovable property. Pierre Bourdieu notes about the inheritance tradition in Kabylia: 'The inheritance tradition, which excludes a woman from their heritage, the mythic world-view which accords her only a limited existence and never grants her full participation in the symbolic capital of her adoptive lineage" (Berger \& Luckmann, 1967). Something similar could be applied to the Georgian case:

A woman is not supposed to be an inheritor. Instead, a man is the only heir. Therefore, all property related issues are charged with symbolic meanings and are in accordance with the structure of society. If a woman also was connected to the continuation of the patrimonial line there could have been a different situation... Lack of economic resources becomes the reason for unequal distribution of inheritance. I think, if the family is a millionaire, then it can give not only houses, but everything to a son and a daughter also...otherwise, people begin to talk about privileges (N. Javakhishvili, expert interview by author, Tbilisi, Georgia, March 2014) 
PROBLEMS

OF MANAGEMENT

IN THE $21^{\text {st }}$ CENTURY Vol. 9, No. 3, 2014

192

This is a really deeply rooted assumption that the main inheritor should be a man, and a woman should be satisfied with a dowry consisting of money or immovable property.

A woman would only be dowered with immovable property if a family owned multiple apartments. If the property consists of land in the village with the family house, then undoubtedly it will go to a son. It is so unquestionable that even women have no feeling of protest. If a woman expresses her dissatisfaction, she is seen as a plotter who does not respect the traditions and does not love her family. Her action is perceived as unseemly and is criticized by society in the micro 'socium' (L. Khomeriki, expert interview by author, Tbilisi, Georgia, March 2014).

The land was everything. A woman got married and moved from her parents' family. Because it was the norm for a woman to move in [with her] new family after getting married, a man became dominant; he did not have to move anywhere. Everything was familiar to him as the house belonged to him. He continued not only a generational, but also a cultural line (V. Mosiashvili, expert interview by author, Tbilisi, Georgia, March 2014).

As mentioned above, it is necessary to acknowledge that the unequal distribution of inheritance is an economic form of violence that may cause other forms of violence. Women, in many cases, suffer from this violence when, often, they are unable to feed or care for themselves and their children. In many cases, parents do not allow their daughters to come back home, even when they are victims of domestic violence. Thus, in a certain sense parents appear to be oppressors of their daughters. On the other hand, before creating new families, women are already doomed to be victims, as they are not independent economically. They do not get an equal and fair part of their inheritance through their dowry. Therefore, initially they are victims of discrimination from their parents. In this sense, we may consider unequal inheritance distribution as a form of violence against women. Iris Marion Young argues: "If unconscious behavior and practices reproduce oppression, they must be morally condemnable" (Young, 2011).

A gendered based distribution and management of inheritance perpetuates an unequal division of positions between sexes, not only in a family, but also in a society. The previously discussed forms of discrimination coming from a woman's parents are not treated as violence. Even in cases of domestic violence in which inheritance could help a woman leave her situation and start over, Georgian women often do not dare to take legal action against their brothers in order to claim their inheritance, especially if their brothers are married. The relationships between blood-related kin are too sacred within Georgian culture to risk violating traditions. However, women are occasionally willing to sue for inheritance rights from their in-laws:

There was a case of two brothers equally possessing a house. Then one of them died. Another brother did not want to share his inheritance with his sister-in-law, who was the legal heiress of her husband. Generally, litigations between sisters-in-law and brothers-in-law happen quite frequently. Now, they do not care about awkwardness, though that could ruin their relationship (T. Koridze, expert interview by author, Tbilisi, Georgia, March 2014)

A woman goes to court when living conditions are hard and sometimes she has no place to stay with her kids. Her childhood house now belongs to her brothers. Her original family thinks her new family should care of her. But if it became impossible to stay there and if she does not want to end up in the street, she has to find a solution, that is, to sue her brotherin-law (L. Khomeriki, expert interview by author, Tbilisi, Georgia, March 2014).

There were many cases when women stayed in the street with infants and when we asked them why they did not go back to their parents' house; all of them had similar responses: because I have a brother and sister-in-law, they live in that house and the property 
belongs to them. The problem is that they do not know their rights and even do not oppose their parents. As usual, parents themselves decide that any property belongs to their sons. We had many such cases; we gave shelter to these women and provided them with various services... Even though we instructed them about their rights they were not ready to discuss their cases at court... Many of them suffered from extreme domestic violence, but still stayed at husband's house, since they could not go anywhere. Their original families did not want them to return home. Generally they try to persuade daughters to be patient and avoid the fate of [becoming a] "divorced woman" (N. Chikhladze, expert interview by author, Tbilisi, Georgia, March 2014).

All experts interviewed for this report emphasized that eliminating the cultural constraints that prevent women from receiving their full inheritance would increase their chances to acquire economic and symbolic capital, independence, status, and power.

Of course, if they (brother and sister-M.A.) divide a property equally than they could unify their share with their husbands/wives properties. As a result, the amount of property would not change, but we would witness a lot of changes in terms of dominance and dependence issue. Husband and Wife would begin cohabitation with the same start-up conditions. This is not acknowledged now (M. Tsereteli, expert interview by author, Tbilisi, Georgia, March 2014).

In the past, women from noble families who inherited their parents' property, since in their families there were no male heirs, frequently were in the same dominant positions as men. We can trace the same practice today. When a financially strong woman marries, she becomes dominant. The financial situation, changes many things (V. Mosiashvili, expert interview by author, Tbilisi, Georgia, March 2014).

It is clear, that in terms of inheritance common law is more effective than inheritance law regulations. Legislative intervention was not enough to eradicate traditional forms of violence on women. We cannot say that nothing has changed, but the improvements in this field still fall short of real change. There are several NGOs working on gender projects, also some significant steps were made in terms of scholarly researches and publications. However, this issue is mainly discussed within certain privileged groups, and has not reached ordinary citizens who actually face such discrimination:

Time goes on and the situation is the same, but some things have changed drastically compared to my childhood. This is connected with the right of expression of free will. To sum up, nowadays, society is freer... (M. Tsereteli, expert interview by author, Tbilisi, Georgia, March 2014).

I cannot say that there is no progress. There are improvements. Generally, the work conducted has its results. The situation is not hopeless, but we need to do more. (N. Javakhishvili, expert interview by author, Tbilisi, Georgia, March 2014).

Of course I am far from the idea that even 1/3 of Georgian society understands that they should share their inheritance equally... But the tendency is that more and more women express their claim and more parents acknowledge their mistake when a son gets the main share of the property.... But the situation is looking up very slowly and if the process is not accelerated by means of new measures it will take a long period until we have real results (T. Koridze, expert interview by author, Tbilisi, Georgia, March 2014).

According to Georgian human rights activist Tamar Gurchiani, Georgia's participation in these international conventions is less motivated by a belief in our adherence to the conventions, and more concerned with the prestige and benefits of being part of a "club" of democratic countries: 
PROBLEMS

OF MANAGEMENT

IN THE $21^{\text {st }}$ CENTURY Vol. 9, No. 3, 2014

194
Why did we join them? .... Developing countries are happier to sign these conventions than developed ones. For example, the USA has not ratified the CEDAW by UNDP... developing countries are happy to ratify these international conventions as they feel like they joined an international club; they need it to get investments, recognition of the state, to develop tourism and so on. There are plenty of reasons (T. Gurchiani. Expert interview by author, Tbilisi, Georgia, March 2014).

Joint attempts of the Government and NGOs to elaborate a complex approach could be seen as initial measures to improve women's positions in term of collecting inheritance. Particularly, a proactive law, information campaign, new programs in education, more women representatives in parliament and the government will play important roles in this process. Nowadays, female representation in parliament is only $11 \%$ and only $38 \%$ of citizens evaluate women's representation as 'too few.'[Public attitudes in Georgia: Results of a March 2013 survey carried out for NDI by CRRC. This research is funded by the Swedish International Development Cooperation Agency (Sida)]

There is a lot to be done in order to encourage women to participate actively in social and political life. The experiences of Poland show us that for several years, it was very difficult for women to enter into political circles, especially for feminists. As Elzbeita Matynia describes, "For a long time it was considered political suicide for a woman active in public life to identify herself with feminism and feminist issues" (Matynia, 2010). But a few years later, an impressive "cohort of women finally 'graduated' in Poland and began to enter the politically relevant public sphere" (Matynia, 2010). That significantly changed the situation in Poland. The same way could be helpful for Georgia. Georgian experts provided some general recommendations:

Currently, I am not actively involved in women's movements and am observing the situation from outside. I have not noticed in any campaign or on TV how many women are victims of family violence because their parents did not support them with a place to live, how many women are oppressed by brothers or sisters and sons-in-law. This data could be collected. Someone should gather this information and publish it to make people think about this issue (M. Tsereteli, expert interview by author, Tbilisi, Georgia, March 2014).

M. Tsereteli discusses why gender related projects are not financed in Georgia. While NGOs usually suggest issues and projects to donor organizations, in Georgia, the process is reversed: NGOs seek donors and these donors suggest courses of study or action. Furthermore, the fields related to the study of gender equality are often filled with unqualified and easily dismissed scholars:

... NGOs should provide adequate work on this issue. The dosage and techniques of transferring information are also important, because when someone thinks that an existing practice is the norm you should not tell her categorically that her rights are abrogated. She might not get it. Therefore, to explain the issue in the correct way you need to have the necessary skills. Many have worked improperly. If you have a bad reputation as soon as you start to speak about gender related problems she would say that she does not want to listen to you (M. Tsereteli, expert interview by author, Tbilisi, Georgia, March 2014).

What short and long term goals should NGOs and government focus on in order to improve this situation? We, who work on gender, say that we need both together: symptomatic treatment that means state [sanctioned] temporary norms and restrictions...And, secondly, working in-depth to fight stereotypes; that means organizing trainings, programs at schools and universities; discussions, meetings, film screenings, and all possible ways to deliver information we should work on with society; We will not have the results today or tomorrow, but we need both approaches to have the results some time [in the future]... There is a need for a strong movement. In this case the problem is that this patriarchal men- 
tality permeates the whole society. The government consists of members with patriarchal mentality and most of them are men. It is a closed circle, if among them were women, not only women but also those without a patriarchal mentality, they could notice problems (N. Javakhishvili, expert interview by author, Tbilisi, Georgia, March 2014).

In Iraq, $30 \%$ of parliament members are women, while in Georgia we have only $11 \%$ of members are women. According to the international standards, at least $30 \%$ of parliament members should be women. When women are not among decision makers in politics, it is natural, that the political will to protect women is weak (T Gurchiani, expert interview by author, Tbilisi, Georgia, March 2014).

Not in kindergarten, but at school we should teach people civic education and explain what male and female equality means. Not only in the legal context, but also in real life; when people create families and have to share inheritance, they should keep a balance and not make preferences on the basis of gender (L. Taliuri, expert interview by author, Tbilisi, Georgia, March 2014).

To summarize the expert interview findings, it can be concluded, that the Republic of Georgia was highly motivated to participate in international conventions as it gave possibility to get benefits and prestige on an international level. However, only liberal legislation was not enough to overcome such widespread form of economic violence as unequal inheritance distribution and management. Georgian women still are not willing to demand equality and defend their rights in this context, since the blood-related kinship is too sacred within Georgian culture. Even though in many cases, women become breadwinners, they cannot be decision makers. They still depend on their husbands when it comes to the management of family issues. Women rather feel more comfortable to fit into the pseudo status and stereotype of "exemplary" Georgian woman. Moreover, females who are victims of violence cannot rely on support from old family and return to their childhood home as they lost their share of it. Consequently, women end up in a situation of suffering from domestic violence. Thus, even though gender inequality is obvious, often it is not perceived as discrimination. On the contrary, some forms of violence are justified on the basis of widespread social and cultural norms condoning such behavior.

\section{Conclusions}

In conclusion, in most Georgian families men have significant privilege in terms of inheritance management. Even though legislation gives men and women equal rights to inheritance, Georgian families give privilege to men and transfer a significant part of the parents' property to men (especially unmovable property). The legislative intervention has not been enough to eradicate traditional form of violence against women. Commonly, male privilege is explained with the logic that they are continuers of a patrimonial lineage. For a Georgian woman, it is more valuable to maintain a good relationship with family than to defend her rights, even though it gives her more chances for self-realization and security. A woman stays economically dependent on her husband, unless she starts to work. In some cases, this creates an inescapable situation of domestic violence as the woman has nowhere to go. Dowries have lost their significance and, unlike in medieval Georgia, are no longer a prerequisite for marriage. Nowadays, with dowries, mostly seen as a symbolic gift, women receive even less property and resources from their parents. Although women have more independence in choosing their spouses, the economic violence of unequal inheritance distribution has a great impact on their independence and individual rights. Unfortunately, despite the myriad negative repercussions of this tradition, the unequal distribution and management of inheritance is often justified by Georgian society, and is not acknowledged as violence or discrimination. 
PROBLEMS

OF MANAGEMENT IN THE $21^{\text {st }}$ CENTURY Vol. 9, No. 3, 2014

The situation, regarding the acknowledgment of gender inequality and injustice has changed, but to get to the desired results, the Georgian government and NGOs should work on developing a complex program that will cover both legal empowerment and education. Such an approach would be productive for short and long-term goals in terms of inheritance management to encourage a more equal and just society for women. Educational programs will change the situation step-by-step in terms of transforming ideas at a personal and cultural level, but to accelerate the process, it is necessary to apply proactive laws, provide various informational campaigns, and encourage more women to take part in politics and public activity.

\section{References}

Bendeliani, N. (2012). Gender equality in Georgia on the bases of international indices and ratings. Tbilisi: Center for Social Sciences.

Beqaia, M. (1980). Social problems of family development. Tbilisi: Metsniereba.

Beqaia, M. (1981). The importance of family and marriage traditions for keeping the strength of modern Georgian family. Tbilisi: Metsniereba.

Bourdieu, P. (2005). Outline of a theory of practice. Cambridge University Press.

Berger, P. L., \& Luckmann, T. (1967). The social construction of reality. Anchor Books.

Elshtain, J. B. (1997). The democratic rule of law. In S. Myers (Ed.), In S. Myers (Ed.), Democracy is a Discussion (pp. 19-20). New London: Connecticut College.

Galston, W. A. (1997). The Role of citizens: Rights and responsibilities. In S. Myers (Ed.), Democracy is a Discussion (p. 7). New London: Connecticut College.

Kohak, E. (1997). The faces of democracy looking to the twenty century. In S. Myers (Ed.), Democracy is a Discussion (pp. 2-4). New London: Connecticut College.

Machabeli, N. (1978). Marriage institute in Kartli. Tbilisi: Metsniereba.

Matynia, E. (2010). Feminism between the local and the global: A task of translation. In A. Basu (Ed.), Women's movements in global era: The power of local feminisms (pp. 193-229). Boulder: Westview Press.

Palous, M. (1997). The role of citizens: rights and responsibilities. In S. Myers (Ed.), Democracy is $a$ Discussion (pp. 36-37). New London: Connecticut College.

National Democratic Institute (NDI). (2013, April 23). Public attitudes in Georgia: Results of March 2013 Survey. Retrieved from https://www.ndi.org/print/20254.

National Democratic Institute (NDI). (2014, April). Public attitudes in Georgia: Results of April 2014 survey. Retrieved from https http://www.civil.ge/files/files/2014/NDI-PoliticalRatings-April2014. pdf

United Nations in Georgia. (2013). Research report: public perception on gender equality in politics and business. Retrieved from http://www.ungeorgia.ge/eng/publications/agencies_publications?info_ id $=77 \#$.VFeGP mUdiw

Sabedashvili, T. (2007). Gender and democratization: Georgia 1991-2006. Tbilisi: Center for Social Sciences.

The Constitution of Georgia (1995, August 24) Retrieved from http://www.parliament.ge/ge/kanonmdebloba/constitution-of-georgia-68

The Law of Georgia on Gender Equality (2010, March 26) Retrieved from http://www.civilinlaw.org/ Project/p1150.pdf

Young, I. M. (2011). Justice and the politics of difference. New Jersey: Princeton University Press.

Advised by Emzar Jgerenaia, Ilia State University, Georgia

Received: November 03, 2014

Accepted: December 28, 2014

Maia Araviashvili

PhD Student and Lecturer, llia State University, M. Aleksidze St \#1, Block 3, Apt.

N17., Tbilisi, 0193, Georgia.

E-mail: m_araviashvili@yahoo.com 